\title{
MOKSLINIAI FILOSOFIJOS RAMSČIAI
}

\author{
Andrius Konickis
}

Kultūros, filosofijos ir meno institutas, Mokslo filosofijos ir istorijos skyrius,

Saltoniškių g. 58, LT-08105 Vilnius, el. paštasnromuva@takas.lt

Iškeliama ir svarstoma tezè, kad filosofija nèra (netgi negali ir neturi büti) mokslas. Pagrindinis argumentas: mokslas tiria ir pažista objekta (arba pasauli apskritai), filosofija ji apmasto, bet netiria ir nepažista. Dabartine postmodernistiné situacija dar labiau išryškina mokslo ir filosofijos kontrasta ir kelia rimtu abejoniu dèl mokslo statuso.

Reikšminiai žodžiai: filosofija, mokslas, tyrimas, mąstymas, postmodernizmas.

Filosofams itin būdinga kelti klausimą „Kas yra filosofija?" ir kartais net smarkiai ginčytis dèl atsakymo ị tokị klausimą. Kiti profesionalai paprastai greičiau sutaria dèl savo profesijos esmès. Neteko girdèti, kad bankininkai keltų klausimą „Kas yra bankininkystė?“ arba vairuotojai diskutuotų, ką reiškia „vairuoti automobilį“. Kad ir kaip nelengva būtų tiksliai apibrèžti, kas yra menas ar politika, vis dèlto visiškai priešingų menininkų ar politikų nuomonių apie savo amatą pasigirsta nedažnai. Galbūt taip yra todèl, kad filosofija - iš esmès ne profesija, o gyvenimo būdas. „Maža yra specialiai atsidedančių filosofijai. Bet bendrąja prasme kiekvienas žmogus yra filosofas..." - pastebi Juozas Girnius (1991: 486), o Antanui Maceinai čia buvo, matyt, dingstis reziumuoti: „Jau vien tai, kad kiekvienas mąstytojas („kiekvienas žmogus“, pasakytų J. Girnius - A. K.) aptaria filosofiją vis savaip, ìspejja mus nepasitikèti iš anksto nè vienu aptarimu“ (Maceina 1994: 12). Nekomplikuodamas be reikalo ir taip sudètingos filosofijos apibrèžimo problemos savąja (ypatingaja?) definicija, noréčiau sutelkti dèmesi tik ị vieną didžiojo klausimo „Kas yra filosofija?" aspektą - i „klausimèlị", ar filosofija yra mokslas. Čia gal išties paprasčiau: galimi tik du atsakymai, belieka pasirinkti - „taip“ arba „ne“.
Nepretenduoju į šių mano svarstymų detektyvini pikantiškumą, iškart pabrèžiu, kad renkuosi atsakymą „ne“ ir tiesiog méginsiu ji šiek tiek argumentuoti - vẻlgi su kai kuriomis išlygomis: kadangi ne kartą - viešai ir privačiai - teko šiuo klausimu diskutuoti remiantis įvairiomis praeities koncepcijomis, šisyk pasistengsiu mažiau apeliuoti ị garsiuosius pirmtakus bendraminčius ${ }^{1}$ ir veikiau pasitelksiu paprasčiausius logiškus (tiesiog žmogiškus) argumentus, nors tam tikrų pasikartojimų išvengti, matyt, nepavyks.

Mèginant bent kiek pažvelgti ì problemą istoriškai, pravartu būtų prisiminti A. Maceinos žodžius: „Savo turiniu ji (filosofija - A. K.) yra išnešiojusi ir pagimdžiusi visus mokslus, su jais tačiau nesusiliedama ir jų neatstodama: visų mokslų motina pati nèra mokslas" (Maceina 1994: 11). Atkreipkime dèmesị: tokia idèja kaip sui generis atsakymas ị klausimą „Ar filosofija yra mokslas?" - o ir pats klausimas - galejo iškilti tik mūsų laikais, bent jau ne per seniausiai - susidarius ir nusistovejjus daugybès

1 Jų išties nemažai; paminéčiau bent kelis-artimiausius: Juozas Girnius (1991), Antanas Maceina (1994, ypač p. 127-167), Arvydas Šliogeris (žr., pavyzdžiui, Transcendencijos tyla. Vilnius: Pradai, 1996, p. 111-143). 
specialiųjų mokslų diferenciacijai. „Pradžioje“, filosofijai vos rakantis iš pirmapradès nediferencijuotos išminties, kurioje dar tik slypejo būsimų menų ir mokslų užuomazgos (kai vienas žynys buvo visai savo bendruomenei astronomas ir muzikantas, gydytojas ir buhalteris, poetas ir agronomas), apie tai nebuvo né susimąstoma. Net Aristotelis, didysis menų ir mokslų klasifikuotojas, filosofiją smagiai vadino mokslu, tačiau ịžvelgè esminị jos ir - tada taip buvo galima sakyti - kitų mokslų skirtumą: „...vvisi kiti mokslai būtinesni už ji (Aristotelis čia filosofiją vadina dieviškuoju mokslu apie priežastis ir pradus $-A$. $K$.), bet geresnio nèra nè vieno" (Metafizika, 983a). Du tūkstančius metų filosofija įvairiai sąveikavo su vadinamaisiais kitais mokslais: buvo ir „mokslų mokslas“, ir kai kurių iš jų - pavyzdžiui, teologijos (juk ne šiaip sau mokslas - apie Dievą!) - tarnaitè, ir vèl „visų mokslų karalienë“, o pagaliau vos netapo visų mokslų tarnaite. Tokias pareigas jai norèjo paskirti Auguste'as Comte’as, pastebėjęs, jog visas „pozityvias“ žinias teikia konkretūs mokslai: filosofijai lieka nebent bendrosios mokslų metodologijos funkcija. Nors tai ir ne itin akivaizdu, bet vis dèlto galima pastebèti, kad Aristotelis ir Comte'as kalba apie tą pati reiškinį: filosofija neturi konkretaus („pozityvaus") tyrimo objekto, taigi iš esmès nèra mokslas ir todèl praktiškai nenaudinga. $\mathrm{O}$ štai mąstytojų išvados visiškai skirtingos; bent jau - emociškai tai aiškiai matyti - Aristotelis lieka filosofas, Comte'o simpatijos veikiau mokslo pusèje. Buvo ir po Comte'o, t. y. jo paskelbtoje trečioje, „pozityvioje“, dvasios stadijoje tikrų filosofų, aiškiai suvokiančių mokslo ir filosofijos skirtingumą ir nėmaž dèl to mokslui nepavydinčių; tačiau buvo ir norinčiųjų paversti filosofiją "griežtuoju mokslu“. Panagrinèkime šią ịdomią situaciją nesiremdami nei vienų, nei kitų argumentais.

Konstatavus (tam tikroje kompanijoje), kad filosofija nèra mokslas, dažnai tenka išgirsti nuoširdų nusistebejjimą: o kas gi tuomet? - lyg būtų paskelbta gryniausia nesąmonè. İdomu, jog pasakęs (toje pačioje kompanijoje), kad, pavyzdžiui, menas arba religija nèra mokslas, panašios reakcijos neišgirsi: juk aišku, kad ne mokslas - menas yra menas, o religija yra religija. Filosofijai kažkodèl tokio savarankiškumo nepripažìstama, manoma, kad ją tiesiog būtina priskirti kokiai nors autoritetingai dvasinei sričiai, lyg teiginys „filosofija yra filosofija“ būtų nesuprantamas ar bent jau nepakankamas. Beje, priskiriama ji tik prie mokslo srities, nes, atrodo, posakiai „filosofija nèra menas“ arba „filosofija - ne religija“, juo labiau - „ne sportas“, „ne žemdirbystë“ ar pan. jokių prieštaravimų ar nesusipratimų nesukelia. Tiesiog nežinau, kodèl mokslui suteikiama tokia privilegija, skiriama garbinga ir atsakinga filosofijos globejjo funkcija. Girdejjau tokių argumentų: juk filosofams suteikiami mokslo daktarų laipsniai, profesorių vardai, universitetuose veikia filosofijos katedros (šalia matematikos ar biologijos katedrų)... Ar tai rimtai? Muzikos akademijoje yra fortepijono, dirigavimo katedrų, dailès akademijoje dèsto tapybos ar keramikos profesoriai - ar dèl to priskirtume šias meno šakas mokslui? O ir oficiali filosofijos kvalifikacija kaip „humanitarinio mokslo“ yra grynai nomenklatūrinis sumanymas, kad profesionaliai dirbantys filosofai galètų gauti atlyginimą už savo triūsą - juk už gyvenimo būda pinigai paprastai nemokami...

Pasvarstykime svarbiausią ir, ko gero, problemiškiausią filosofijos moksliškumo aspektą. Vienas iš pagrindinių mokslo skiriamųjų požymių, neatsiejamas jo atributas yra tam tikras tyrimo, pažinimo objektas. Kartais sakoma, - jeigu, pavyzdžiui, fizikos objektas yra gamta, - kad fizika yra mokslas apie gamtą. Apie ką gi yra „mokslas“ filosofija? Koks yra filosofijos „mokslo“ pažinimo, tyrimo objektas? Per gana ilgą filosofijos istoriją buvo pateikta nemažai įdomių formuluočių, tačiau visos jos lieka abejotinos ir net kritikuotinos remiantis vienu vieninteliu pamatiniu principu. Paméginsime tai pademonstruoti paèmę vieną būdingą ir dar tikriausiai nepamirštą - nes itin populiarų nesenais tarybiniais laikais - filosofijos apibrèžimą. Jis skelbia, kad filosofija yra „mokslas apie 
bendriausius gamtos, visuomenès ir mąstymo vystymosi dèsnius“2. Pirmiausia dera pastebèti, kad mokslai paprastai yra ne „apie désnius“, o apie objektus; jie formuluoja dèsnius, šiuos objektus tirdami ir pažindami. Ogi visi trys išvardyti objektai turi ir be filosofijos juos tiriančius ir pažistančius mokslus: gamta yra fizikos objektas, visuomenè - sociologijos, mąstymas - logikos. Nuoroda i „ „bendriausius dèsnius“ tikriausiai yra mėginimas išvengti šio keblaus sutapimo ir pasikartojimo. Betgi kiekvienas mokslas pajègus, be abejo, suformuluoti ir konkretesnius, ir bendresnius dèsnius - pastariesiems visiškai nereikalingas koks nors specialus mokslas. Maždaug šitaip galima sukritikuoti ir Aristotelio mokslą „apie priežastis ir pradus“: ligų priežastis tiria etiologija, nusikaltimų - kriminalistika (galbūt ir psichologija), žmonių visuomenès ir civilizacijos pradus bando atskleisti istorija ir archeologija. Beje, Aristotelis, aišku, kalbèjo apie būties (pasaulio apskritai, viso, kas yra) priežastis ir pradus. Antikos laikais tai skambejjo visai natūraliai, bet ilgainiui mokslas tokių absoliučių pretenzijų atsisakè. Atleiskime Aristoteliui už tokią „nevykusią“ terminiją: atrodo, kad šitaip jis norejjo būtent atskirti filosofiją nuo mokslo.

Kitą, iš pažiūros kiek švelnesnị, variantą nurodyti filosofijos objektą (objektus) reprezentuoja, pavyzdžiui, Evaldo Nekrašo Filosofijos ivadas. Šių objektų klasifikaciją randame jau knygos turinyje - metafizika, gamtos filosofija, pažinimo teorija, mokslo filosofija, etika, politinè filosofija, o Antrojo leidimo pratarmeje

${ }^{2}$ Idomu, kad greta funkcionavo ir kita filosofijos - na, gal ne definicija, bet, tarkime, - charakteristika kaip vienos iš vadinamosios visuomeninès samonès formu. Kitos šios visuomenines samonés formos buvo mokslas, menas, morale, religija ir, atrodo, ideologija. Atkreipkime dèmesį: visi šie reiškiniai (taigi ir filosofija ir mokslas) yra lygiagretūs. Formaliosios logikos terminais galetume sakyti: šiu sąvoku (klasiu) santykis yra nuošalè arba - jeigu esama bendru elementu-perkirtimas, bet ne subordinacija; né viena iš ju nera kitos dalis (poklasis). Tokioje sistemoje nieko nestebina, kad religija yra religija, bet ne vienas iš menu, o filosofija yra filosofija - ne mokslas apie ka nors... pasakyta, kad „knygos skyriai pavadinti filosofijos skyrių vardais“ (Nekrašas 2004: 11), lyg filosofija turètų tokius skyrius kaip, pavyzdžiui, matematika: aritmetika, algebra, geometrija ir kt. J. Girnius šiuo atžvilgiu atrodo gerokai ¡žvalgesnis ir filosofiškesnis; jis pirmiausia pabrèžia, kad „filosofija, kaip būties klausimas, savo pagrinde yra vienas klausimas. Apskritai filosofijoje nèra tokios specializacijos, kokia yra atskiruosiuose moksluose", o šiuos - sit venia verbo - skyrius taikliai vadina „disciplinomis“ ir papildo sąrašą dar dvasios, arba žmogaus, filosofija, teodicèja, logika, kultūros filosofija ir čia pat droviai teisindamasis, kad taip mat „vadovèliškai ipprasta“ (Girnius 1991: 487-488). Aišku (ar bent jau taip istoriškai susiklostè), kad šie dalykai labiau domina filosofus nei, tarkime, bankininkystès ar žemès ūkio problemos, jei filosofija, kaip ją gražiai apibūdina J. Girnius, yra „mąstymas, kuriuo žmogus ieško atsakymo ¡̣ būties klausimą rūpindamasis savo egzistencijos iprasminimu mirties akivaizdoje“ (Girnius 1991: 480). Tačiau ir jie, suvokiami kaip tyrimo ir pažinimo objektai, turi arba eventualiai gali turèti juos tiriančius ir pažistančius mokslus; kitaip tariant, šios J. Girniaus vadinamosios „disciplinos“ gali būti - prireikus - traktuojamos kaip tam tikri mokslai. Atrodo, jog susidaro keistas nesusipratimas; o juk čia ir slypi esminis, paprastai sunkiai įžvelgiamas (A. Comte'o, pavyzdžiui, visiškai nepastebètas) mokslo ir filosofijos skirtumas. Bet ar iš tikrujų ji taip sunku suvokti? Aptarkime tai kiek išsamiau.

Mokslas tiria, pažista objektą (arba apskritai - pasauli); filosofija ji apmąsto, bet netiria ir nepažissta. Šia prasme visai logiška būtų sakyti, jog mokslas nemąsto (šitaip pasakęs M. Heideggeris tarsi atsiprašo - „tai nèra joks priekaištas“ - pernelyg kaprizingų mokslininkų, kurie dèl to kaipmat raukiasi tartum būtų išvadinti kvailiais). Mokslas tiria metodiškai - taikydamas metodą kaip ịrankį, tarpininką, o pažindamas formuluoja dèsnius. Filosofija neturi metodo kaip tarpininko ir neformuluoja jokių dèsnių, nebent idejas - beje, šis „nebent“ nėmaž filosofinių idejų nesumenkina. Herakleito paradoksai (kaip antai „ne- 
galima dukart ịbristi ị vieną upę“), Platono idejų pasaulis, Descartes'o cogito ergo sum, Spinozos Deus sive substantia sive natura, Kanto kategorinis imperatyvas - ne dèsniai, o idejos; jos nèra universalios ar visiems privalomos kaip, tarkim, gravitacijos dèsnis ar daugybos lentelè, tačiau jos nesensta kaip, pavyzdžiui, daugybė Aristotelio (kaip mokslininko!) biologijos teiginiu, ir negali būti „atšauktos“, kaip, pavyzdžiui, Ptolemejjo geocentrinè sistema. Net ir Hegelio vadinamieji dialektikos dèsniai (priešybių vienybès, neigimo neigimo ir kt.) nèra dèsniai sensu stricto, nors ir galètume nurodyti aibę pavyzdžių, iliustruojančių ar patvirtinančių jų nusakomus raidos, sąveikos principus - desningumus; veikiau tai yra savotiškas mąstymo būdas. Filosofijos „metodu“ (quasi metodu) galima būtų laikyti nuo Antikos žinomą nuostatą: nustebti-suabejoti-paklausti; bet tai yra mąstymo, o ne tyrimo, ne pažinimo metodas. Paguoskime vèlgi mokslininkus: niekas neatima iš jų teisès stebètis, abejoti ir klausti, o tiriant nepažǐstamą reiškinị ar objektą tai yra itin veiksmingos procedūros. Tačiau kalbant apie filosofiją tai nèra skverbimosi ị nepažǐstamą objektą būdas, o veikiau - pakartokime tai dar syki - modus vivendi. Filosofas nustemba nuolat ties paprasčiausiais, kasdieniškais dalykais, suabejoja ten, kur kitiems žmonès nekyla jokių abejonių, ir klausia - pirmiausia ir dažniausiai pats savęs - to, kas visiems yra seniausiai aišku savaime. Todèl bet kuris daiktas ar reiškinys gali tapti filosofinio apmąstymo objektu, o esant pakankamai ilgalaikems ir vaisingoms tokio mąstymo tradicijoms gali susiformuoti vadinamieji „filosofijos skyriai“, kaip juos ivvardija E. Nekrašas, arba „disciplinos“, jei vartotume J. Girniaus terminiją. Iš tokių pirmųjų filosofų susidomejjimo objektų kaip gamta, pažinimas, moralè, grožis kilo natūrfilosofija, gnoseologija, etika, estetika; vèliau atsirado ir jau gana tradicinèmis tapo kalbos filosofija, meno filosofija, mokslo filosofija, kultūros filosofija. Visai natūraliai kuriasi ar bent jau gali susikurti verslo, karo, sporto, televizijos, sekso filosofijos, jei tik šiuos ir su jais susijusius dalykus imsime apmąstyti filosofiškai. Šios kartais sąmojingai vadinamos „kilmininko filosofijos“ gali teikti ìdomių idèjų, bet negali suformuluoti jokių dèsnių - tam reikalingi specialūs mokslai; kai kuriems minètiesiems objektams tirti tokie mokslai egzistuoja (pavyzdžiui, ekonomika, seksologija ir kt.), kitiems prireikus gali būti sukurti.

Pridurkime dar, kad šiuos ar kitus objektus tiriantys mokslai formuluoja - turi formuluoti! - universalius dėsnius, kurių nepaisyti nevalia. Nors iš pagarbos I. Newtonui dèsnị, nusakanti pagreičio priklausomybę nuo kūno masès ir ji veikiančios jègos $a=F / m$, vadiname garsiojo mokslininko vardu, jis vienodai reikšmingas visiems inžinieriams, konstruojantiems naujus automobilius ir puikiai išmanantiems fiziką, ir visiems valstiečiams, vežimu gabenantiems bulves ir nieko nei apie šią formulę, nei apie jos išradèją negirdejjusiems. Filosofinès idejos, nors gali sudominti, o neretai ir labai stipriai paveikti, iš esmès funkcionuoja tik jas suformulavusio filosofo sistemoje ar koncepcijoje: apmąstant moralès problemas galima remtis Aristotelio dorybiu ir ydu simetrija (ar asimetrija), bet galima ir visiškai ją ignoruoti. Net jeigu keli filosofai ar netgi kelios filosofų kartos gali būtų priskirti kokiai nors srovei, krypčiai ar mokyklai, įdomiausi ir vertingiausi jie yra individualiai, o ne kaip komandos nariai: M. Heideggeris ir J. P. Sartre'as yra gana (jei nedrịstume pasakyti visiškai) skirtingi filosofai, nors abu tradiciškai laikomi egzistencializmo atstovais. Ar galètume isivaizduoti šitiek fizikos, geografijos, botanikos, o kad ir istorijos ar ekonomikos „srovių“ ir „krypčių“, kiek jų atsirado vien XX amžiaus filosofijoje, juo labiau - aibę „individualių“ geografijų, botanikų ar ekonomikų? Tokiam košmarui išvengti pakanka atidžiau įsižiūrèti ir pamatyti, kad mokslinis tyrimas ir pažinimas iš esmès skiriasi nuo filosofinio mąstymo, o mokslo dèsnis - nuo filosofinès idejos...

Kita vertus, apmaudu būtų nematyti daugelio filosofijos ir mokslo panašumų, o neigti juos užsispyrus būtų neprotinga. Tačiau atkreipkime dèmesị ì akivaizdų principą: 
konstatuojant kokių nors dviejų dalykų panašumus kaip tik ir pabréžiama, kad jiedu yra panašūs, bet ne tapatūs. Juk nesunku nurodyti pluoštą, tarkim, filosofijos ir meno arba filosofijos ir religijos panašumų, bet ar derètų dèl to manyti, kad filosofija yra menas arba religija? Keletas idejų dèl filosofijos ir poezijos panašumo ar net giminystès galètu savotiškai pailiustruoti mus čia dominančią mokslo ir filosofijos koliziją. Štai A. Maceina teigia, kad „filosofija ir poezija ne tik iš bendro šaltinio (kalbos) kyla, bet nešasi ir bendrą turini, kuriuo yra žmogiškasis būties suvokimas ir pergyvenimas“ (Maceina 1990: 38). Jam pritaria J. Girnius, ịsitikinęs, kad filosofija ir poezija „eina ì viena... i t pačią būties visumą“ (Girnius 1942). H. G. Gadameris pabrèžia, jog „poetinis žodis dèl savo vidinio sąvokingumo yra nepaprastai artimas filosofinei sąvokai“ (Гадамер 1991: 155). Panašių minčių rasime M. Heideggerio, P. Valéry tekstuose, o šiaip rimtai svarstyti ši įspūdingą filosofijos ir poezijos giminingumą pradejo J. G. Herderis ir vokiečių romantikai. Tačiau nè vienas šių mąstytojų neketino poezijos ir filosofijos sutapatinti. J. Girnius, pavyzdžiui, sako „nepamirštąs, kad poezija nèra filosofija“ (Girnius 1989: 72), o T. Venclova net itin kategoriškai pabrèžia: „Dviejų ženklų sistemų - poetinès ir filosofinès - negalima suplakti ị vieną: poezija yra tiek filosofinè, kiek ji lieka poezija, ir filosofija yra tiek poetiška, kiek ji lieka filosofija“ (Venclova 1991: 348). Tiesa, A. Maceinai kartą išsprūdo: „Savo esmèje filosofija ir poezija yra tas pats dalykas“ (Maceina 1990: 40), bet gal manykime, kad tai yra specialiame kontekste pavartota poetinè hiperbolè arba - paprasčiausiai - filosofinè idejja ad hoc: juk aišku, kad tai ne mokslinio tyrimo išvada, ir vargu ar mąstytojas bandytų šią „tezę“ kaip nors moksliškai ịrodyti... Taigi - grịžtant prie mokslo ir filosofijos - ar nesutiksime, kad juo daugiau ir juo įdomesnių aptinkame mokslo ir filosofijos panašumų, juo įsakmiau derètų pabrèžti esminị jų skirtumą? Arba, jeigu žūtbūt reikia apginti mokslo elementus filosofijoje, pasakykime kiek perfrazavę T. Venclovos pastabą: filosofija yra tiek moksliška, kiek ji lieka filosofija.

Ivertinkime pagaliau mokslo ir filosofijos situaciją dabartiniame pasaulyje, taigi jų santykị i̊sigalint - jau įsigalejus? - postmodernistinei mąstymo ir kūrybos (apskritai - gyvenimo) paradigmai. Jau gana seniai pastebėta, jog vienas iš esmingiausių mūsų postmodernios epochos bruožų yra tai, kad nuolat ir sparčiai „dingsta kai kurios pagrindinès ribos ar skirtybès" (Jameson 2002: 17). Dažniausiai kalbama apie aukštosios profesionalios kultūros susiliejimą su vadinamąja masine, populiariąja, tačiau aiškiai matyti ir bendrasis, visuotinis kultūros ir ekonomikos aljansas bei kai kurios lokalios jo atmainos - meno ir biznio, sporto ir politikos, mokslo ir reklamos, netgi verslo ir nusikalstamumo simbiozè. Neretai net religiją sunku atskirti nuo politikos, biznio, meno, turizmo ir kitų visuomeninių reiškinių. Tai iš dalies primena senuosius, sakytume, kultūros pradžios laikus; gal iš tikrųjų - grị̌iimas ì pirmapradị nediferencijuotą kultūrinị vienį? Anaiptol. Dabartinès kultūros reiškiniai suartejja, bet nesusilieja, juo labiau nesusitapatina. Menininkas teikia ir vykdo visokiausių tarptautinių fondų dosniai finansuojamus „projektus“ ir šitaip daro savo bizni - bet juk nesunku atskirti iš esmès, kur tame vadinamajame projekte menas, o kur biznis. Panašiai galbūt koks apsukrus verslininkas, gudriai rašydamas sąskaitas ir ataskaitas, sèkmingai išvengia teismų ir kalejjimų, bet iš principo juk aišku, - ir pats verslininkas tai žino geriau už kitus, - kur yra „balta“, o kur „juoda“ buhalterija. Taigi, matyt, visuotinis postmodernistinis „ribų ir skirtybių“ išnykimas dar nèra pagrindas liautis iš esmès skyrus filosofiją ir mokslą kaip gana savitas vis dèlto kultūros sritis. Tačiau yra kita problema, tiksliau - gal kitas tos pačios problemos aspektas, ị kurị taip pat atkreipia demesị F. Jamesonas: „<..> nyksta senosios žanro ir diskurso kategorijos <...>“. Tarkime, kaip vadintini Michelio Foucault darbai - filosofija, istorija, socialine teorija ar politiniu mokslu?" (Jameson 2002: 17). Pastebèkime, kad tai nèra koks nors netikètas postmodernizmo atradimas: kaip vadinsime, 
pavyzdžiui, B. Pascalio Mintis, Dante’s Dieviškaja komedija, Marko Aurelijaus Sau pačiam, o ir daugybę kitų puikių pasaulinės klasikos tekstų, parašytų gerokai anksčiau, nei postmodernistas Michelis Foucault apskritai išmoko rašyti raides. Keblumas, matyt, slypi kiek giliau. Pats rašantysis - bent jau humanitarinejje srityje, jei paliksime ramybejj gamtos mokslus, kur, atrodo, viskas daugmaž aišku - negali būti vienareikšmiškai priskirtas tam tikram intelektualinių darbuotojų luomui. Rimčiausia, žinoma, yra mokslo ir filosofijos kolizija, nes anaiptol ne visuomet galima tiksliai nustatyti, ar humanitaras formuluoja savo mokslinio tyrimo ir pažinimo rezultatus, ar filosofiškai mąsto ir siūlo skaitytojui savo idejas ${ }^{3}$. O jeigu dar atsižvelgsime i humanitarams gana būdingą politinị arba religinị angažuotumą, polinkị i moralizavimą arba didaktiką, pagaliau ị poetinị kūrèjo ịkvėpimą, matysime, kad apie koki nors tikslesni teksto žanrą nèra nè kalbos. Ir pritarsime tikriausiai F. Jamesonui, rekomenduojančiam šiuo atveju kiek niveliuojančią sąvoką „teorinis diskursas“, nes, prievarta pavertę filosofiją mokslu, problemos tikrai neišspręsime. Gal netgi sukomplikuosime: mat nors F. Jamesonui ir atrodo, kad šio neaiškaus pobūdžio diskurso atsiradimas „nužymi pačios filosofijos užbaigą" (Jameson 2002: 17), mokslo statusas postmodernizmo sąlygomis kelia kur kas daugiau abejonių. „Postmodernizmo filosofijoje ir moksle padarinys, - reziumuoja, pavyzdžiui, grupé lenku filosofų, - yra universaliai suvokiamos tiesos ir universalių pažinimo metodų, mąstymo ir veiklos schemų atmetimas $\langle\ldots\rangle$. Taigi absoliuti tiesa pasirodo esanti reliatyvi ir visada dalinè, pažinimas virsta begaline interpretacija $<\ldots$.. “ (Słownik filozofii 2004: 407-409). Filosofijai tai nėmaž netrukdo, nes ji iš principo nepretenduoja ị visuotinę ir galutinę tiesą ar ị išsamų ir tikslų kokio nors objekto pažinimą; tačiau mokslui tai yra vis dèlto gana rimtas iššūkis. Galètų tad pirštis tiesiog priešinga intencija: gal derètų iš esmès peržiūrèti mokslo statusą, gal mūsų pažintinis optimizmas neturi tokio pamato kaip anksčiau galèjo atrodyti...

Tačiau nereikalaučiau primygtinai jokios stulbinančios mokslo revizijos, visiškai nenoréčiau kaip nors jo „sufilosofinti“, atimti iš jo esminių, tradicinių tyrimo ir pažinimo funkcijų. Juo labiau nemanau, kad mokslo statuso neturinti filosofija negali būti respektuojama kaip savita intelektualinès veiklos ir kūrybos sritis. Tad tiesiog klausčiau: ar, parèmę filosofiją moksliniais ramsčiais, nesugriausime esminių jos pačios pamatų?

\section{Literatūra}

Girnius, J. 1942. „Poezija ir filosofija“, I laisvę, 1942, lapkričio 28.

Girnius, J. 1989. „Žmogaus prasmès žemèje poezija“, iš Egzodo literatūros atšvaitai. Vilnius: Vaga.

Girnius, J. 1991. „Filosofija“, iš Raštai, t. I. Vilnius: Mintis.

Jameson, F. 2002. Kultūros posūkis. Vilnius: Lietuvos rašytojų sąjungos leidykla.

Maceina, A. 1990. “Cor inquietum”, iš Raštai, t. III. Vilnius: Mintis.

Maceina, A. 1994. „Filosofijos kilmè ir prasme““, iš Raštai, t. VI. Vilnius: Mintis.

Nekrašas, E. 2004. Filosofijos ịvadas. Vilnius: Mokslo ir enciklopedijų leidybos institutas.

Słownik filozofii. 2004. Warszawa: Świat Książki.

Venclova, T. 1991. „Atmenanti žeme““, iš Vilties formos. Vilnius: Lietuvos rašytojų sąungos leidykla.

Гадамер, Х. Г. 1991. „Лирика как парадигма современности“, в кн. Актуальност прекрасного. Москва: Искусство.
${ }^{3}$ Labai noréčiau, kad skaitytojas, remdamasis savo kriterijais ir pažiūromis, pats nustatytų, ar šis tekstas priskirtinas moksliniam žanrui, ar filosofiniam. 


\section{SCIENTIFIC SHORES FOR PHILOSOPHY}

\section{Andrius Konickis}

A thesis that philosophy is not (and even cannot and has not to be) science is posed and discussed. The main argument is that science investigates an object and forms a knowledge of it, while philosophy ponders over an object or the world on the whole but does not investigate anything. Contrast between science and philosophy becomes more and more distinct under conditions of postmodernism because of serious doubts as to the status of science.

Keywords: philosophy, science, investigation, pondering, postmodernism.

Iteikta 2006-04-21; priimta 2006-06-21 